\title{
KAJIAN HADIS DALAM PERSPEKTIF LIBERAL
}

\author{
Fakhrurrozi \\ Program Studi Pendidikan Bahasa Arab STAI As-Sunnah Deli Serdang \\ Jl. Medan-Tg. Morawa, Km. 13 G. Darmo, Desa B. Sari, Kec. Tg. Morawa Kab. Deli Serdang \\ ro.zi24@yahoo.co.id
}

\begin{abstract}
Abstrak: Liberal tidak terpaku terhadap teks-teks Agama baik dari Alquran maupun Hadis, tetapi lebih terikat dengan subtansi yang terkandung dalam teksteks tersebut. Pokok-pokok pemikiran liberal antara lain ialah: mengakui pluralitas Agama, bahwa nilai islami itu bisa terdapat pada semua tempat, di semua agama, dan semua suku bangsa. Oleh karena semua agama memiliki tujuan yang sama, subtansi yang sama, nilai-nilai universal yang sama, maka sebagai implikasinya pembedaan antara muslim dengan non-muslim harus dihapuskan. Menurut Liberal, Muhammad tidak lebih dari sekedar tokoh historis yang harus dikaji secara kritis, oleh karenanya, tidak wajib meniru Rasulllah secara leterlek. Kehadiran Rasulullah di tengah-tengah masyarakat bertujuan untuk merubah konteks Arab dari peradaban Jahiliyah menuju peradaban Islamiyah. Atas dasar itu pula, umat Islam harus mampu menerapkan nilai itu sesuai dengan konteks yang ada dalam bentuk yang lain.
\end{abstract}

Kata Kunci: Pemikiran Hadis, Perspektif Liberal

\section{Pendahuluan}

Ajaran Islam yang dibawa oleh Nabi Muhammad saw., telah menyebar dalam waktu yang relatif cepat di dunia dan mewarnai sisi-sisi kehidupan manusia. Perubahan masyarakat yang berlangsung dalam abad pertama Islam tiada bandingannya dalam sejarah dunia. Kesuksesan Nabi Besar Muhammad saw., dalam merombak masyarakat jahiliyah Arab, membentuk dan membinanya menjadi masyarakat Islam, masyarakat bermartabat, masyarakat terpelajar, masyarakat berdisiplin, masyarakat industri, masyarakat sejahtera adalah tuntunan yang sangat sempurna dan wahyu ilahi.

Bersamaan dengan perguliran waktu, perubahan zaman, politik dunia dan sosial budaya eksternal, kesempurnaan dan keindahan Ajaran Islam yang telah terbukti mampu mengangkat harkat dan martabat manusia dunia tak terkecuali di Indonesia, terkotori oleh berbagai pemikiran yang menyimpang dengan segala motif dan latar belakangnya. Salah satunya adalah fenomena pemikiran liberal dalam ajaran Islam. Dengan menggunakan istilah-itilah manis, seperti: Islam modern, pembaharuan Islam, Islam moderat, Islam rasional, dan istilah-istilah 
manis lainnya, pemikiran Islam Liberal banyak membuahkan pendapat-pendapat yang kontroversial tentang ajaran Islam.

\section{Pembahasan}

\section{Mengenal Liberal}

Pada tahun 2001, Jaringan Islam Liberal (JIL) didirikan di Jakarta. Dengan nama jaringan, JIL berusaha menjadi komunitas tempat para aktivis muslim berinteraksi dan bertukar pandangan secara bebas. ${ }^{1}$ Sedangkan kemunculan istilah Islam Liberal ini, menurut Luthfie, mulai dipopulerkan tahun 1950-an. Tapi mulai berkembang pesat terutama di Indonesia-tahun 1980-an, yaitu oleh tokoh utama dan sumber rujukan "utama" komunitas atau Jaringan Islam Liberal, Nurcholish Madjid. Meski Nurcholish sendiri mengaku tidak pernah menggunakan istilah Islam Liberal untuk mengembangkan gagasan-gagasan pemikiran Islamnya, tapi ia tidak menentang ide-ide Islam Liberal. Karena itu, Islam Liberal sebenarnya "tidak beda" dengan gagasan-gagasan Islam yang dikembangkan oleh Nurcholish Madjid dan kelompoknya. Yaitu, kelompok Islam yang tidak setuju dengan pemberlakuan syariat Islam (secara formal oleh negara), kelompok yang getol memperjuangkan sekularisasi, emansipasi wanita, "menyamakan" agama Islam dengan agama lain (pluralisme teologis), memperjuangkan demokrasi Barat dan sejenisnya. $^{2}$

Pada dasarnya, latarbelakang pemikiran liberal mempunyai akar yang jauh sampai di masa keemasan Islam. Teologi rasional yang dikembangkan oleh muktazilah dan para filsuf, seperti al-Kindi, al-Farabi, Ibn Sina, Ibn Rusyd dan sebagainya, selalu dianggap telah mampu menjadi perintis perkembangan kebudayaan modern dewasa ini.

Charless Kurzman menyebutkan bahwa Islam liberal muncul sekitar abad ke-18 di kala kerajaan Turki Utsmani Dinasti Shafawi dan Dinasti Mughal tengah berada di gerbang keruntuhan. Pada saat itu tampillah para ulama untuk

\footnotetext{
${ }^{1}$ Budi Handrianto, 50 Tokoh Islam liberal Indonesia, (Jakarta: Hujjah Press, 2007), h. xiiv.

2 Menembus Batas Tradisi menuju Masa Depan yang Membebaskan: Refleksi atas Pemikiran Nurcholis Madjid, h. 113-114.
} 
mengadakan gerakan permurnian, kembali kepada Alquran dan sunnah. Bersamaan dengan ini muncullah cikal bakal paham liberal awal melalui Syah Waliyullah di India, 1703-1762, menurutnya Islam harus mengikuti adat local suatu tempat sesuai dengan kebutuhan pcnduduknya. Hal ini juga terjadi dikalangan Syi'ah. Ada Muhammad Bihbihani di Iran, 1790, mulai berani mendobrak pintu ijtihad dan membukanya lebar-lebar.

Ide ini terus bergulir. Rifa'ah Rafi' at-Tahtawi di Mesir, 1801-1873 memasukkan unsur-unsur Eropa dalam pendidikan Islam. Sebelum dikirim ke Sorbonne, Perancis oleh Muhammad Ali, yang saat itu menjadi kepala negara Mesir, Tahtawi adalah seorang tradisionalis. Dia adalah salah seorang anggota delegasi pertama dari negara Muslim yang dikirim ke Barat. Dari sini bisa dikatakan bahwa tradisi pengiriman Muslim ke Barat adalah mengikuti tradisi tahtawi. Hampir semasa dengan Tahtawi, di Rusia muncul Shihabuddin Marjani (1818-1889) dan Ahmad Makhdun di Bukhara, 1827-1897, memasukkan mata pelajaran sekuler ke dalam kurikulum pendidikan Islam. ${ }^{3}$

Di Mesir muncullah M. Abduh (1849-1905) yang banyak mengadopsi pemikiran muktazilah, berusaha menafsirkan Islam dengan cara yang bebas dari pengaruh salaf. Abduh adalah murid al-Afgani yang paling menonjol, tapi pengaruhnya melebihi gurunya karena latarbelakang keagamaannya.

Muhammad Abduh dan al-Afgani merupakan tokoh pembaruan Islam yang beraliran liberal awal. Setelah revolusi Arab oleh murid-murid al-Afgani yang dipimpin oleh Ahmad Arabi, saat itu Abduh jadi Syekh al-Azhar, maka Abduh diasingkan ke Beirut. Hasil revolusi Arab adalah Mesir dikendalikan oleh Inggris.

Setelah pulang dari pembuangan karena bantuan Inggris, Abduh pindah haluan, dari revolusi menjadi reformasi (modernisasi) yang intinya adalah: mendekatkan Islam dengan Barat atau menyesuaikan ajaran Islam dengan budaya dan peradaban Barat. Hal ini telah dimulai oleh Abduh saat ia mendirikan lembaga pendekatan antara agama-agama di Barat. Akhirnya atas petunjuk

\footnotetext{
${ }^{3}$ Charles Kurzman, Wacana Islam Liberal: Pemikiran Islam Kontemporer tentang Isu-isu Global, (Jakarta: Paramadina, 2003), h. 14-16.
} 
Konsul Inggris di Mesir, Abduh diangkat jadi Mufti Mesir. Abduh memandang bahwa jihad yang ada dalam Islam hanyalah membela diri, intinya ia ingin bermesraan dan bergandengan tangan dengan orang kafir, meskipun Mesir, negerinya sendiri dijajah para penyembah salib. ${ }^{4}$

Pada masa kontemporer, pemikiran liberal di dunia Arab muncul beberapa nama seperti Mohammed Arkoun, Hasan Hanafi, Fazlur Rahman dan Muhammad Abid Jabiri. Muhammad Arkoun lahir di al-Jazair pada tahun 1928 kemudian menetap di Perancis. Ia menggagas tafsir Alquran model baru yang didasarkan pada berbagai disiplin Barat seperti dalam lapangan semiotika (ilmu tentang fenomena tanda), antropologi, filsafat dan linguistik. Intinya Ia ingin menelaah Islam berdasarkan ilmu-ilmu pengetahuan Barat modern. Dan ingin mempersatukan keanekaragaman pemikiran Islam dengan keanekaragaman pemikiran diluar Islam. ${ }^{5}$

Di Pakistan muncul Fazlur Rahman (lahir 1919) yang menetap di Amerika dan menjadi guru besar di Universitas Chicago. Ia menggagas tafsir konstekstual, satu-satunya model tafsir yang adil dan terbaik menurutnya. Ia mengatakan Alquran itu mengandung dua aspek: legal spesifik dan ideal moral, yang dituju oleh Alquran adalah ideal moralnya karena itu ia yang lebih pantas untuk diterapkan. ${ }^{6}$

Akhirnya gagasan Islam liberal ini sampai ke Indonesia melalui murid Fazlur Rahman yaitu Nurcholish Madjid. Nurcholis Madjid adalah murid dari Fazlur Rahman di Chicago yang memelopori gerakan liberal bersama dengan Djohan Effendi, Ahmad Wahib dan Abdurrahman Wahid. Nurcholis Madjid telah memulai gagasan pembaruannya sejak tahun 1970-an. Pada saat itu ia telah menyuarakan pluralisme agama.

Dari gambaran di atas, dapat disimpulkan bahwa lahirnya pemikiran liberal Islam di Indonesia tidak terjadi begitu saja. Munculnya pemikiran liberal

\footnotetext{
4 Sulaiman al-Kharasi, al-Asraniyah Qantarah al-'Almaniyah, (al-Karashi @ Hotmail.com; Majalah al-Bayan vol. 149/1421), h. 70,82,83.

${ }^{5}$ W. Montgomery Watt, Kerajaan Islam: Kajian Kritis dari Tokoh Orientalis, (Yoyakarta: Tiara Wacana Yogya, 1990), h. 143.

${ }^{6}$ Ibid.
} 
Indonesia tidak terlepas dari pemikiran liberal dari dunia Arab, juga tidak terlepas dari pengaruh pemikiran keagamaan di Amerika dan di Eropa. Di benua Amerika telah lama berkembang pemikiran keagamaan yang mengarah pada rekontekstualisasi doktrin agama. Sementara di Eropa telah berkembang pula pemikiran keagamaan yang sangat "radikal" yakni pemikiran tentang perlunya reaktualisasi pemikiran keagamaan khususnya di kalangan katolik dan Protestan. ${ }^{7}$

2. Tokoh-tokoh Liberal di Indonesia

Untuk melancarkan usahanya, tokoh-tokoh liberal di Indonesia bekerja sama dengan para intelektual, penulis, dan akademisi dalam dan luar negeri, untuk menjadi kontributorya. Di antara tokoh-tokoh liberal di Indonesia adalah sebagai berikut: ${ }^{8}$

1. Nurcholish Madjid, Universitas Paramadina Mulya, Jakarta.

2. Charles Kurzman, University of North Carolina.

3. Azyumardi Azra, IAIN Syarif Hidayatullah, Jakarta.

4. Abdallah Laroui, Muhammad V University, Maroko.

5. Masdar F. Mas'udi, Pusat Pengembangan Pesantren dan Masyarakat, Jakarta.

6. Goenawan Mohamad, Majalah Tempo, Jakarta.

7. Edward Said.

8. Djohan Effendi, Deakin University, Australia,

9. Abdullahi Ahmad an-Naim, University of Khartoum, Sudan.

10. Jalaluddin Rahmat, Yayasan Muthahhari, Bandung.

11. Asghar Ali Engineer.

12. Nasaruddin Umar, IAIN Syarif Hidayatullah, Jakarta.

13. Mohammed Arkoun, University of Sorbonne, Prancis.

14. Komaruddin Hidayat, Yayasan Paramadina, Jakarta.

15. Sadeq Jalal Azam, Damscus University, Suriah.

16. Said Agil Siraj, $P B N U$, Jakarta.

17. Denny JA, Universitas Jayabaya, Jakarta.

\footnotetext{
${ }^{7}$ Ra'fat Salah ad-Din, Wa Saqata Sanamu al-Libraliyah, h. 4-7.

${ }^{8}$ Adian Husaini dan Nuaim Hidayat, Islam Liberal; Sejarah, Konsepsi, Penyimpangan dan Jawaban,(Jakarta: Gema Insani Press, 2002), h. 05.
} 
18. Rizal Mallarangeng, CSIS, Jakarta.

19. Budi Munawwar-Rahman, Yayasan Paramadina, Jakarta.

20. Ihsan Ali-Fauzi, Ohio University, AS.

21. Taufik Adrian Amal, IAIN Alauddin, Ujung Pandang.

22. Hamid Basyaib, Yayasan Aksara, Jakarta.

23. Ulil Abshar Abdalla, Lakpesdam-NU, Jakarta.

24. Luthfi Assyaukanie, Universitas Paramadina Mulya, Jakarta.

25. Saiful Mujani, Ohio State University, AS.

26. Ade Armando, Universitas Indonesia, Depok.

27. Syamsurizal Panggabean, Universitas Gadjahmada, Yogyakarta. ${ }^{9}$

Selain tokoh-tokoh di atas, beberapa orang tokoh Muhammadiyah juga aktif mendukung gagasan Islam Liberal, seperti Abdul Munir Mulkhan dan Sukidi. Bahkan Ketua PP Muhammadiyah, Syafii Maarif juga dapat dikategorikan ke dalam pendukung gagasan Islam Liberal. Seperti diketahui, Maarif adalah pendukung gagasan-gagasan liberal (Neo-Modernisme) Fazlur Rahman. ${ }^{10}$

Gerakan pemikiran liberal terus digalakkan oleh tokoh-tokoh tersebut meskipun kemunculannya mendapatkan reaksi yang cukup keras dari umat Islam di Indonesia. Kalangan Islam Liberal bergerak melalui jalur-jalur universitas, LSM, dan pusat-pusat studi, baik di lingkungan kampus maupun lainnya, selain juga menggelar diskusi-diskusi publik, dengan tema-tema yang menjadi isu utama mereka seperti demokrasi, pluralisme, kesetaraan gender, dan HAM. ${ }^{11}$

3. Pemikiran Liberal

a. Hadis menurut Liberal

Kaum liberal selain menggugat Alquran ${ }^{12}$, mereka juga menggugat otentisitas hadis, dan meruntuhkan otoritas (hujjiyyah)-nya sebagai salah satu sumber asasi dalam hukum Islam. Dalam hal ini, liberal tentunya tidak sendiri.

\footnotetext{
${ }^{9}$ Lihat juga: Hartono Ahmad Jaiz, Aliran dan Paham Sesat di Indonesia, (Jakarta: Pustaka al-Kausar, 2009), h. 235-236.

${ }^{10}$ Adian Husaini, Islam Liberal, h.16.

${ }^{11}$ Zuly Qodir, Islam Liberal, Varian-Varian Liberalisme Islam di Indonesia 1991-2002, (Yogyakarta: LKiS, 2010), h. 109.

${ }^{12}$ Taufik Adnan Amal, Edisi Kritis Al-Qur'an, disunting oleh Luthfi Assyaukanie, Wajah Liberal Islam di Indonesia, (Jakarta: Jaringan Islam Liberal, 2002), h. 87.
} 
Ada orientalis yang menjadi rujukan utama mereka. ${ }^{13}$ Gugatan orientalis terhadap hadis bermula pada pertengahan abad ke-19 masehi, tatkala hampir seluruh bagian dunia Islam telah masuk dalam cengkeraman kolonialisme bangsa-bangsa Eropa. Alois Srenger adalah yang pertama kali mempersoalkan status hadis dalam Islam. Dalam pendahuluan bukunya mengenai riwayat hidup dan ajaran Nabi Muhammad saw. Misionaris asal Jerman yang pernah tinggal lama di India ini menyatakan bahwa hadis merupakan anekdot. Pernyataan ini diikuti oleh rekan satu misinya William Muir, Orientalis Inggris yang juga mengkaji biografi Nabi Muhammad saw. sejarah perkembangan Islam. Menurut Muir, dalam litertur hadis, nama Nabi Muhammad sengaja dicatat untuk menutupi bermacam-macam kebohongan dan keganjilan. ${ }^{14}$

Dapat disimpulkan bahwa kaum liberal meragukan eksistensi sunnah sebagai dasar hukum Islam. Menurut mereka para sahabat tidak dapat dipercaya, sistem yang dibangun ulama hadis pun tidak dapat dipertanggungjawabkan secara ilmiah dan butuh koreksi ulang. ${ }^{15}$ Dari sini jelaslah bahwa para penganut pemikiran liberal masih meragukan keabsahan hadis sebagai hujah, dan otomatis pandangan ini berimplikasi pada sisi materil atau hukum-hukum yang diatur di dalamnya.

b. Iman Minimalis

Iman dalam perspektif liberal sangat simpel dan sederhana. Jika belakangan ini, sayap iman semakin meluas ke mana-mana, itu sesungguhnya ulah ulama dan hasil kreasi umat belakangan. Iman menurut perspektif Alquran hanya lima butir, sedangkan menurut hadis hanya satu. Oleh karena itu, untuk menjadi muslim yang sempurna imannya, cukup hanya mengimani enam butir itu saja. Di luar itu sebenarnya bukan kehendak Tuhan, melainkan ijtihad para ulama. Atas dasar itu pula, siapa pun tidak berhak membidahkan orang lain apalagi

\footnotetext{
${ }^{13}$ Muhammad Hamid an-Nasir, al- 'Asraniyyun Baina Maza `im at-Tajdid wa Mayadin atTagrib, (Riyad: Maktabah al-Kausar, cet. II, 2001), h. 62.

14 Arham, Analisa Kaum Liberal Indonesia terhadap Hukum Islam, Tesis mahasiswa UI Fakultas Hukum, (Jakarta: 2011), h. 41.

${ }^{15}$ Contohnya adalah hadis tentang khasiat memakan kurma demikian juga hadis tentang lalat. Lihat Nasir al-'Aqal, al-Ittijahat al-'Aqliyah al-Hadisah, (Riyad: Dar al-Fadilah, 2001), h. 237-240.
} 
mengkafirkannya selama tidak keluar dari enam prinsip pokok di atas. ${ }^{16}$ Yusuf Abu al-Khail dalam sebuah tulisannya, mengatakan:

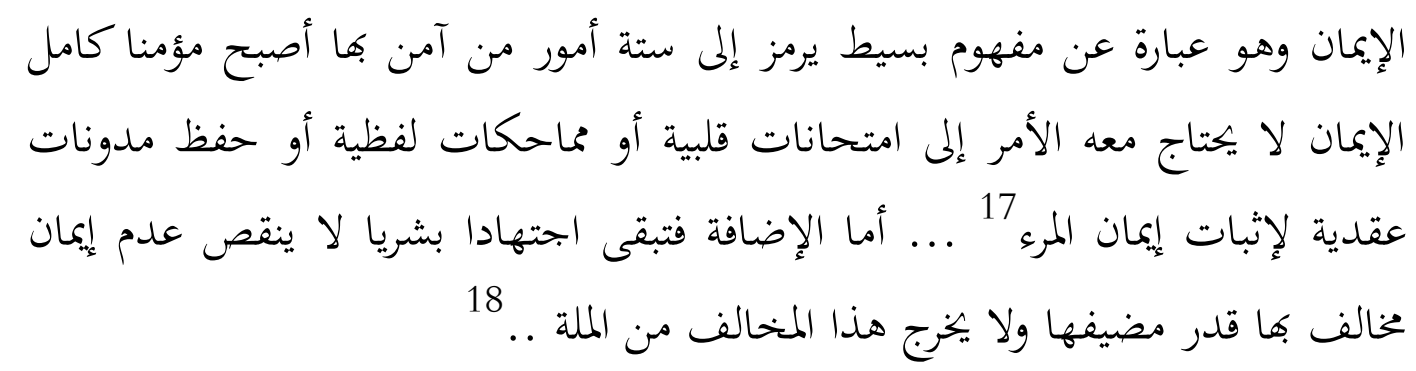

Ucapan di atas tentu sangat berseberangan dengan pendapat jumhur ulama dari dulu hingga sekarang. Bahwa perkara iman tidak hanya terbatas pada rukun iman yang enam saja. Betul rukun iman ada enam, tetapi membatasi perkara iman hanya pada yang enam itu saja, bertentangan dengan hadis Nabi yang berbunyi:

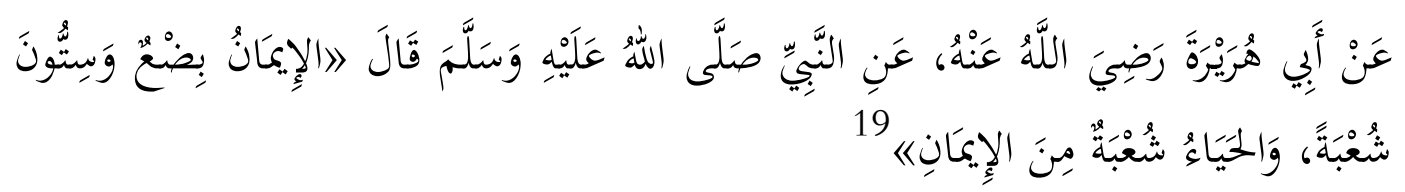

c. Liberalisme, Pluralisme dan Toleransi

Kaum liberal mengadopsi keyakinan agama Kristen protestan, bahwa Nabi Adam sesungguhnya tidak bisa disalahkan ketika beliau memilih untuk memakan buah pohon dan mengabaikan perintah Tuhan. Karena pada prinsipnya, apa yang dilakukan Adam tidak lebih dari sekedar memanfaatkan akal pikiran yang telah dianugerahkan kepadanya. Dalam keyakinan ini, meskipun di satu sisi Adam dianggap salah dan tetap dituntut mempertanggungjawabkan kesalahannya, tetapi di sisi lain ada Isa al-Masih (anak Tuhan) yang akan menebus semua dosa-dosa dan kesalahan manusia. Atas dasar ini lah, pemanfaatan akal diyakini merupakan kebebasan bergaransi seumur hidup untuk semua orang, baik individu maupun masyarakat, ${ }^{20}$ meskipun kemudian harus menabrak kehendak Tuhan. Sebagai konsekwensinya, kebebasan berfikir, kebebasan berekspresi dan kebebasan

\footnotetext{
2011), h. 31 .

${ }^{16}$ Khalifah Ibn Battah al-Khizzi, al-Libraliyyun al-Judud, (al-Qahirah: Dar al-Awa'il,

${ }^{17}$ Ibid.

${ }^{18}$ Ibid. h. 30.

${ }^{19}$ Muhammad Ibn Isma`il al-Bukhari, Sahih al-Bukhari, (t.t.p: Dar Tauq an-Najat, 1422 H), jilid. I, h. 11.

${ }^{20}$ Khalifah al-Khizzi, al-Libraliyyun al-Judud, h. 325-328.
} 
menentukan pilihan melahirkan ijtihad yang bervariasi dan masyarakat yang plural. $^{21}$

Agar prinsip kebebasan dan keragamanan manusia berjalan mulus sesuai dengan harapan, diperlukan sikap toleransi. Sikap toleransi ini diharapkan dapat menjaga kerukunan hidup dan kemaslahatan bersama.

Bila dikaji lebih mendalam, terlihat bahwa target yang diharapkan dari prinsip toleransi ini adalah pemisahan antara agama dan Negara. Diasumsikan bahwa Negara dan politik tidak boleh ikut campur terhadap urusan-urusan pribadi termasuk agama seseorang. Demikian sebaliknya, urusan pribadi dan agama tidak boleh dibawa-bawa kepada dunia politik dan Negara. Pandangan seperti ini sebenarnya berakar dari Negara Eropa dan Barat, kemudian diadopsi oleh kaum liberal dan menjadikannya sebagai sebuah ajaran. Jhone Lok seorang penganut sekuler liberal menekankan sebagai berikut:

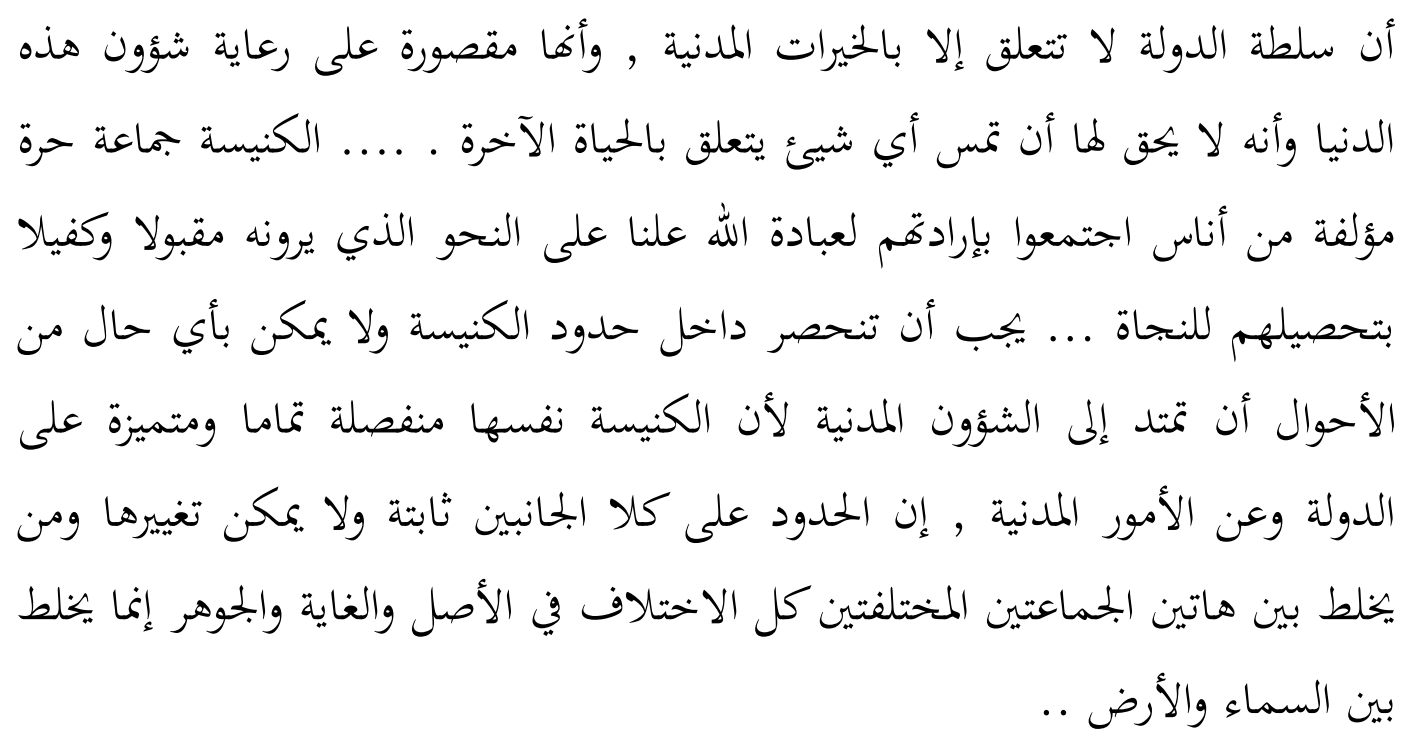

Toleransi seperti ini lah sesungguhnya yang diinginkan oleh kaum liberal. Bahkan lebih jauh dari itu, jika ajaran agama dianggap batu penghalang untuk saling bertoleransi maka agama juga perlu dikritisi dan ditinjau ulang. ${ }^{22}$

${ }^{21}$ Abdul Aziz Ibn Mustafa Kamil, Ma`rakah as-Sawabit baina al-Islam wa al-Libraliyah, h. 82 .

${ }^{22}$ Muhammad Ibn Ahmad Mufti, Naqd at-Tasamuh al-Librali, (Riyad: Majallatu alBayan, 1431 H), h. 21-23. 


\section{d. Relatifisme Moralitas}

Nilai-nilai moralitas yang tumbuh berkembang di tengah-tengah masyarakat harus tunduk pada prinsip kebebasan yang telah dibangun. Jangan sampai menabrak atau meruntuhkan nilai-nilai kebebasan itu sendiri. Diyakini bahwa kehidupan dunia ini berawal dan akan berakhir sampai di sini. Tidak ada yang namanya hari kebangkitan. Sejarah kemanusiaan akan berakhir dengan berakhirnya umur alam semesta, dengan segala kebebasan dan keragamannya. Kehidupan dunia yang singkat ini diyakini sangat suci, di sini lah awal dan akhir segalanya. Puncak ketenangan hidup manusia terletak pada nilai kebebasan itu sendiri. Oleh karenanya, semua nilai-nilai moralitas yang ada dianggap sebagai sesuatu yang relatif dan terbatas, yaitu pada ruang dan waktu tertentu. Bisa jadi cocok untuk satu ruang dan waktu tetapi tidak untuk ruang dan waktu yang lain. Oleh karenanya, penerapan nilai-nilai keadilan bagaimanapun dan siapapun harus tunduk pada prinsip kebebasan yang diyakini kaum liberal. ${ }^{23}$

\section{Liberal dalam Konteks Indonesia}

Liberal tidak mengenal adanya penutupan pintu ijtihad. Sebaliknya, liberal sangat menjunjung kemerdekaan berpikir dan berijtihad. Bahkan, dalam perspektif Jaringan Islam Liberal (JIL), sumber hukum pertama dalam ijtihad adalah akal. ${ }^{24}$ Pemikiran liberal di Indonesia yang saat ini masih eksis tidak murni lahir dari dari warisan para intelektual Indonesia sebelumnya, akan tetapi mempunyai latarbelakang dan asal-usul yang panjang. Pemikiran para intelektual Barat dan para Islamolog juga sangat berpengaruh terhadap tumbuh dan berkembangannya pemikiran liberal di Indonesia. Liberal muncul di Indonesia sekitar tahun 1970-an, terutama setelah munculnya para pemikir dan intelektual yang dianggap liberal, seperti Gus Dur, Nurcholish Madjid, Djohan Effendi dan Ahmad Wahib. Perkembangan pemikiran liberal semakin gencar setelah banyak pelajar dan intelektual muda Indonesia belajar ke universitas atau Perguruan

\footnotetext{
${ }^{23}$ Ibid., h. 83-84.

${ }^{24}$ Lihat: Harun Nasution, Teologi Islam, Aliran-aliran Sejarah Analisa Perbandingan, (Jakarta: UI-Press, 1986), h. 150.
} 
Tinggi di Amerika dan Eropa. ${ }^{25}$ Di antara beberapa gagasan besar yang sampai sekarang masih menjadi trend pemikiran liberal adalah sekularisasi, pluralisme dan kebebasan berfikir. Lebih tegasnya dalam situs Jaringan Islam Liberal, pokok-pokok pemikiran liberal dituangkan secara terbuka sebagai berikut:

Islam Liberal adalah suatu bentuk penafsiran tertentu atas Islam dengan landasan sebagai berikut:

a. Membuka pintu ijtihad pada semua dimensi Islam

Islam Liberal percaya bahwa ijtihad atau penalaran rasional atas teks-teks keislaman adalah prinsip utama yang memungkinkan Islam terus bisa bertahan dalam segala cuaca. Penutupan pintu ijtihad, baik secara terbatas atau secara keseluruhan, adalah ancaman atas Islam itu sendiri, sebab dengan demikian Islam akan mengalami pembusukan. Islam Liberal percaya bahwa ijtihad bisa diselenggarakan dalam semua segi, baik segi muamalat (interaksi sosial), ubudiyyat (ritual), dan ilahiyyat (teologi).

b. Mengutamakan semangat religio etik, bukan makna literal teks

Ijtihad yang dikembangkan oleh Islam Liberal adalah upaya menafsirkan Islam berdasarkan semangat religio-etik Qur'an dan Sunnah Nabi, bukan menafsirkan Islam semata-mata berdasarkan makna literal sebuah teks.

Penafsiran yang literal hanya akan melumpuhkan Islam. Dengan penafsiran yang berdasarkan semangat religio-etik, Islam akan hidup dan berkembang secara kreatif menjadi bagian dari peradaban kemanusiaan universal.

c. Mempercayai kebenaran yang relatif, terbuka dan plural.

Islam Liberal mendasarkan diri pada gagasan tentang kebenaran (dalam penafsiran keagamaan) sebagai sesuatu yang relatif, sebab sebuah penafsiran adalah kegiatan manusiawi yang terkungkung oleh konteks tertentu; terbuka, sebab setiap bentuk penafsiran mengandung kemungkinan salah, selain kemungkinan benar; plural, sebab penafsiran keagamaan, dalam satu dan lain cara, adalah cerminan dari kebutuhan seorang penafsir di suatu masa dan ruang yang terus berubah oritas dan tertindas.

\footnotetext{
${ }^{25}$ Imam Mustafa, Sketsa Pemikiran Islam Liberal di Indonesia, Jurnal STAIN Jurai Siwo Metro.
} 
Islam Liberal berpijak pada penafsiran Islam yang memihak kepada kaum minoritas yang tertindas dan dipinggirkan. Setiap struktur sosial-politik yang mengawetkan praktek ketidakadilan atas yang minoritas adalah berlawanan dengan semangat Islam. Minoritas di sini dipahami dalam maknanya yang luas, mencakup minoritas agama, etnik, ras, jender, budaya, politik, dan ekonomi.

d. Meyakini kebebasan beragama

Islam Liberal meyakini bahwa urusan beragama dan tidak beragama adalah hak perorangan yang harus dihargai dan dilindungi. Islam Liberal tidak membenarkan penganiayaan (persekusi) atas dasar suatu pendapat atau kepercayaan.

e. Memisahkan otoritas duniawi dan ukhrawi, otoritas keagamaan dan politik.

Islam Liberal yakin bahwa kekuasaan keagamaan dan politik harus dipisahkan. Islam Liberal menentang negara agama (teokrasi). Islam Liberal yakin bahwa bentuk negara yang sehat bagi kehidupan agama dan politik adalah negara yang memisahkan kedua wewenang tersebut. Agama adalah sumber inspirasi yang dapat mempengaruhi kebijakan publik, tetapi agama tidak punya hak suci untuk menentukan segala bentuk kebijakan publik. Agama berada di ruang privat, dan urusan publik harus diselenggarakan melalui proses konsensus.

Nama "Islam liberal" menggambarkan prinsip-prinsip yang kami anut, yaitu Islam yang menekankan kebebasan pribadi dan pembebasan dari struktur sosial-politik yang menindas. "Liberal" di sini bermakna dua: kebebasan dan pembebasan. $^{26}$

Pemikiran Islam Liberal Indonesia sebagaimana pada tulisan mereka di atas terlihat sejalan dengan pemikiran liberal lainnya, sebagaimana telah dikemukakan di awal. Namun anehnya, masing-masing tetap mencari-cari pembenaran pemikirannya dari sumber-sumber kewahyuan, baik dari Alquran maupun sunnah.

\footnotetext{
${ }^{26} \mathrm{http}: / /$ islamlib.com/id/halaman/tentang-jil
} 
5. Pandangan Ulil Abshar Abdalla tentang sejumlah hadis ${ }^{27}$

a. Menolak Formalisasi Hukum Islam

Di antara pandangan yang paling menonjol dari kaum liberal adalah penolakan terhadap formalisasi hukum Islam khususnya di Indonesia. Bahkan mereka memandang bahwa sama sakali tidak ada perintah untuk menegakkan sistem hukum yang Islami. Atas dasar itu pula, mereka terpaksa menolak hadishadis Nabi meskipun derajatnya sahih, karena dianggap bertentangan dengan Alquran. Ulil dalam tulisannya pada sebuah artikel mengutarakan pendapatnya tentang riwayat al-Bukhari yang terkenal:

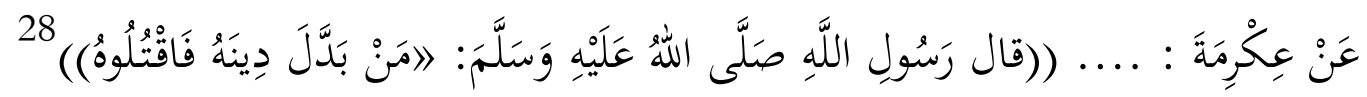

"Hadis ini jelas bertentangan dengan isi Quran, sebab di dalam kitab suci itu tak ada penegasan sama sekali tentang hukum bunuh bagi seorang yang murtad. Hukum bunuh dalam Quran hanya berlaku dalam satu kasus saja, yaitu pidana pembunuhan yang disengaja. Ini yang disebut dengan qisas atau hukum bunuh balas bunuh.

Menurutnya, intinya adalah bahwa hukum bunuh dalam hadis itu tak bisa diterima sebab berlawanan dengan Quran. Hukum bunuh bagi seorang murtad tak dikenal dalam Islam sesuai dengan visi universal Quran mengenai kebebasan memeluk keyakinan.

Sebenarnya penolakannya terhadap hadis di atas bukan semata karena dianggap bertentangan dengan visi Alquran, tetapi karena dianggap bertentangan dengan nilai-nilai kebebasan itu sendiri. Hal ini sejalan dengan apa yang pernah diungkapkan Azyumardi Azra:

"Secara praktis, paham Islam liberal sama sekali tidak menginginkan adanya segala bentuk formalisasi serta radikalisasi sikap keagamaan. Sebaliknya, ia cenderung menempatkan Islam sebagai sebuah sistem dan tatanan nilai yang harus dibumikan selaras dengan tafsir serta tuntutan zaman yang kian dinamis." 29

${ }^{27} \mathrm{http}: / /$ islamlib.com/gagasan/islam-liberal/sejumlah-tesis-mengenai-hadis-nabi/

${ }^{28}$ Al-Bukhari, Sahih al-Bukhari, jilid. IX, h. 15.

${ }^{29}$ Azyumardi Azra dalam pengantar Buku Abd. A`la: Dari Neomodernisme ke Islam Liberal; Jejak Fazlur Rahman dalam Wacana Islam di Indonesia. 
Dari ungkapan-ungkapan di atas, terlihat bahwa pemikiran liberal menolak gerakan formalisasi syariat di Indonesia. Formalisasi dalam politik, hukum, maupun peraturan-peraturan lainnya, hanya akan mengganggu keberagamaan kaum muslimin. Bagi mereka yang terpenting adalah substansinya bukan formalitasnya.

\section{a. Liberalisasi Pemahaman hadis la darara wala dirara}

Oleh karena hadis la darara wala dirara sejajar dengan kaidah utama dalam filsafat liberalisme modern: Anda bebas berbuat apa saja, kecuali perbuatan yang mengganggu kebebasan orang lain, maka hadis ini berjalan dengan mulus, tanpa sedikitpun mendapat kritikan.

Dengan menggunakan bahasa yang kelihatannya objektif, ilmiah, Ulil menyebutkan, "Sebagai penjelasan, hadis bersifat relative, sementara yang absolute adalah pesan-pesan universal dalam Quran. Tetapi tidak semua hadis bersifat spesifik dan terikat dengan waktu. Ada sejumlah hadis yang juga memiliki pesan-pesan universal yang berlaku sepanjang zaman. Oleh karena itu, kita harus memilah antara hadis yang universal dan partikular.

Menurutnya, hadis di atas bisa disebut sebagai hadis universal karena isinya mengandung prinsip yang berlaku sepanjang masa, prinsip tak boleh menimbulkan kecelakaan pada orang lain. Oleh karena hadis ini sejalan dengan semangat kebebasan dan toleransi ala liberal maka hadis ini dapat diterima.

b. Hadis-hadis partikular tidak berlaku lagi saat ini

Kebalikan dari hadis la dara wala dirara, adalah semacam hadis Abi Bakrah yang diriwayatkan oleh al-Bukhari, yang berbunyi: "Lan Yufliha Qaumun Wallau Amarahum Imra'atan”. Bangsa yang menyerahkan kepemimpinan kepada perempuan tak akan berhasil/beruntung. Menurut Ulil, hadis ini terkait dengan situasi tertentu dan tidak bisa ditelan mentah-mentah pada zaman sekarang. Menurutnya, isi dan kandungan hadis ini bersifat spesifik, terkait dengan situasi tertentu, dan tidak berlaku universal. Hadis-hadis yang menyangkut hukum publik biasanya dikategorikan sebagai hadis partikular dan tak bisa lagi diberlakukan saat ini, karena konteksnya sudah berbeda. 


\section{Bebas tetapi Berbatas}

Kebebasan merupakan fitrah penciptaan manusia. Menjalankan misi penciptaan tidak mungkin dilakukan secara sempurna tanpa kebebasan untuk berbuat. Allah swt., telah memuliakan manusia dan memberikan mereka fasilitas yang cukup dalam rangka menjalankan tanggungjawab kehambaan. Allah swt., berfirman:

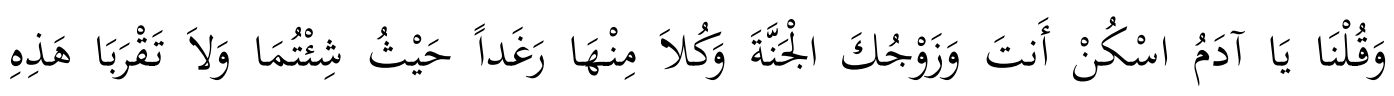

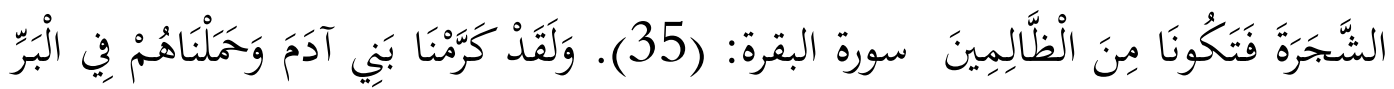

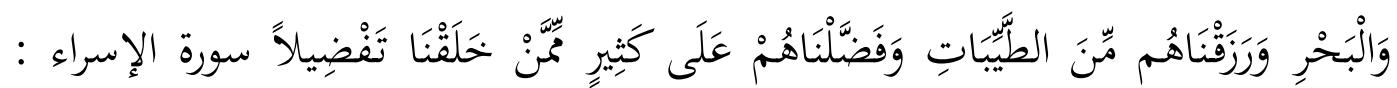

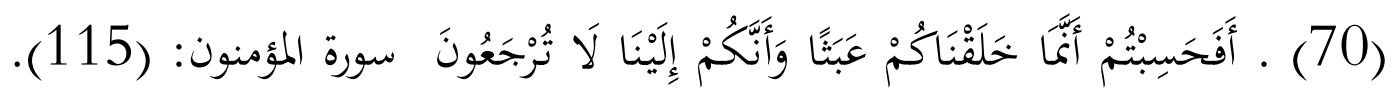

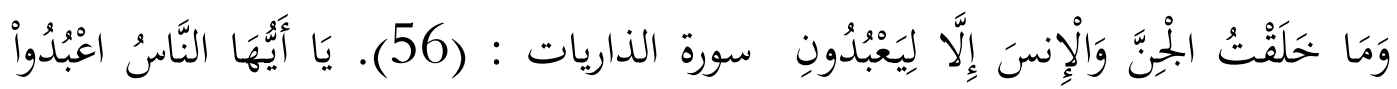

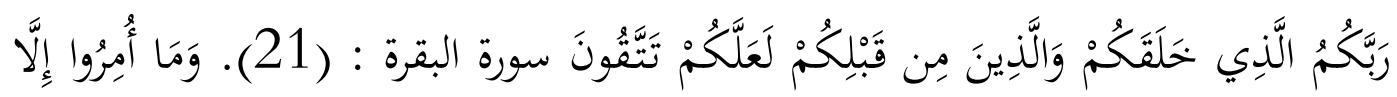

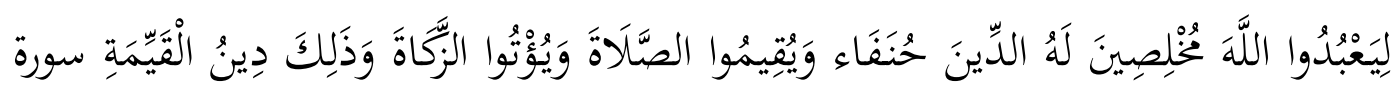
البينة: (5) (5) (15)

Dapat difahami, dari sejak awal Allah swt., telah memberikan kebebasan kepada Adam tetapi tetap dalam ikatan yang terbatas. Adam dan Istrinya Hawa bebas tinggal di Surga dan memakan buah apa saja asalkan tidak pohon yang satu itu. Selain itu, dalam kaidah fikih ada beberapa kaidah yang menunjukkan kebebasan manusia secara luas, antara lain:

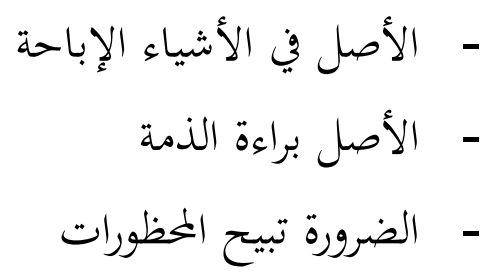

Tetapi kebebasan tersebut tidak harus dipahami secara liberal dan membabi buta. Karena kebebasan tanpa batas bisa berakibat fatal termasuk kufrul istihlal, kufru asy-syak, kufrul imtina`, kufrul hukmi bigairi ma anzalallah. ${ }^{30}$

${ }^{30}$ Abd ar-Rahim Ibn Samail as-Sulami, Haqiqatu al-Libraliyah wa Mauqifu al-Islam minha, Talkhis Iman Binti Muhammad 'Ayid al-Usairi, (t.t.p: Markaz at-Ta'sil li ad-Dirasat wa alBuhus, 2011), h. 88-90. 


\section{Penutup}

Liberal adalah sebuah pemikiran yang sifatnya bebas, yang menurut mereka tidak terpaku terhadap teks-teks Agama baik dari Alquran maupun Hadis, tetapi lebih terikat dengan subtansi yang terkandung dalam teks-teks tersebut. Dalam implementasinya pemikiran ini dapat disebut meninggalkan teks sama sekali, dan hanya menggunakan rasio dan selera belaka.

Rumusan pokok-pokok pemikiran liberal yang berkembang antara lain ialah: mengakui pluralitas Agama, bahwa nilai islami itu bisa terdapat pada semua tempat, di semua agama, dan semua suku bangsa, oleh karena semua agama memiliki tujuan yang sama, subtansi yang sama, nilai-nilai universal yang sama, maka sebagai implikasinya pembedaan antara muslim dengan non-muslim harus dihapuskan. Muhammad adalah tokoh historis yang harus dikaji secara kritis, oleh karenanya tidak wajib meniru Rasulllah secara leterlek. Kehadiran Rasulullah di tengah-tengah masyarakat adalah untuk merubah konteks Arab dari peradaban Jahiliyah menuju peradaban Islamiyah. Atas dasar itu pula, umat Islam harus mampu menerapkan nilai itu sesuai dengan konteks yang ada dalam bentuk yang lain. Memperjuangkan tegaknya syariat Islam adalah wujud ketidakberdayaan umat Islam dalam menyelesaikan masalah secara rasional bijak.

Setelah melihat gambaran pemikiran liberal sebagaimana telah diuraikan di atas dan juga di kitab-kitab lain, penulis berkesimpulan bahwa kelompok ini menyimpang dari ajaran Alquran, Hadis dan Ijmak para ulama, bahkan pada sebagian ucapan yang mereka lontarkan dapat dihukumi sebagai bentuk kekufuran, waliyazu billah.

\section{Pustaka Acuan}

Ad-Din, Ra'fat Salah, Wa Saqata Sanamu al-Libraliyah.

Al-'Aqal, Nasir, al-Ittijahat al-'Aqliyah al-Hadisah, Riyad: Dar al-Fadilah, 2001.

Al-Bukhari, Muhammad Ibn Isma`il, Sahih al-Bukhari, t.t.p: Dar Tauq an-Najat, $1422 \mathrm{H}$, jilid. I.

Al-Khizzi Khalifah Ibn Battah, al-Libraliyyun al-Judud, al-Qahirah: Dar alAwa'il, 2011. 
Amal, Taufik Adnan, Edisi Kritis Al-Qur'an, disunting oleh Luthfi Assyaukanie, Wajah Liberal Islam di Indonesia, Jakarta: Jaringan Islam Liberal, 2002.

An-Nasir, Muhammad Hamid, al-'Asraniyyun Baina Maza im at-Tajdid wa Mayadin at-Tagrib, Riyad: Maktabah al-Kausar, cet. II, 2001.

Arham, Analisa Kaum Liberal Indonesia terhadap Hukum Islam, Tesis mahasiswa UI Fakultas Hukum, Jakarta: 2011.

As-Sulami, Abd ar-Rahim Ibn Samail, Haqiqatu al-Libraliyah wa Mauqifu alIslam minha, Talkhis Iman Binti Muhammad 'Ayid al-Usairi, t.t.p: Markaz at-Ta'sil li ad-Dirasat wa al-Buhus, 2011.

Azra, Azyumardi dalam pengantar Buku Abd. A`la: Dari Neomodernisme ke Islam Liberal; Jejak Fazlur Rahman dalam Wacana Islam di Indonesia.

Handrianto, Budi, 50 Tokoh Islam liberal Indonesia, Jakarta, Hujjah Press, 2007.

http://islamlib.com/gagasan/islam-liberal/sejumlah-tesis-mengenai-hadis-nabi/

http://islamlib.com/id/halaman/tentang-jil

Husaini, Adian dan Nuaim Hidayat, Islam Liberal; Sejarah, Konsepsi, Penyimpangan dan Jawaban, Jakarta: Gema Insani Press, 2002.

Kamil, Abdul Aziz Ibn Mustafa, Ma`rakah as-Sawabit baina al-Islam wa alLibraliyah.

Kurzman, Charles, Wacana Islam Liberal: Pemikiran Islam Kontemporer tentang Isu-isu Global, Jakarta: Paramadina, 2003.

Mufti, Muhammad Ibn Ahmad, Naqd at-Tasamuh al-Librali, Riyad: Majallatu alBayan, $1431 \mathrm{H}$.

Mustafa, Imam, Sketsa Pemikiran Islam Liberal di Indonesia, Jurnal STAIN Jurai Siwo Metro.

Nasution, Harun, Teologi Islam, Aliran-aliran Sejarah Analisa Perbandingan, Jakarta: UI-Press, 1986.

Qodir, Zuly, Islam Liberal, Varian-Varian Liberalisme Islam di Indonesia 19912002, Yogyakarta: LKiS, 2010.

Watt, W. Montgomery, Kerajaan Islam: Kajian Kritis dari Tokoh Orientalis, Yoyakarta: Tiara Wacana Yogya, 1990. 